\title{
Comparison between Antidumping and Countervailing Duties: The Case of the United States International Trade Commission, 1995-1999*
}

\author{
JAI S. MAH \\ College of Commerce, Damkonk University
}

\begin{abstract}
This study compares the determinants of antidumping duties with those of countervailing duties using data for the U.S. ITC under the World Trade Otganization system. The empirical evidences show that the commissioners are responsive to changes in trade balances and unemployment rate. Their decisions in case of antidumping duties are revealed to be less responsive to changes in macroeconomic variables than those relating to countervailing duties. The Democrat Commissioners are revealed to be more responsive to macroeconomic variables than the Republican Commissioners in the case of countervailing duties-telated decisions.
\end{abstract}

Keywords: comparison, determinants, antidumping duties, countervailing duties

I wish to express my sincere thanks to the anunymous referees for their very thoughtful comments. However, of course, all remaining errors are entirely mine. The present research was conducted by the research fund of Dankook University in 2003.

Direct all correspondence to Jai S. Mah, Professor of College of Commerce. Dankook University, Yongsan-ku, Seoul 140-714, Korea; Tel: 82-2-709-2512; E-mail: mahsong@hotmail.com, jsmah59@ yahoo.com 


\section{INTRODUCTION}

7 he average tariff rates of the contracting parties for members of the General 1 Agreement on Tariffs and 'Trade $\left(\mathrm{GA}^{\prime} \mathrm{I}^{\mathrm{N}} \mathrm{T}\right)$ and the World Trade Organization (WTO) have been reduced substantially with the progress of several multilateral trade negotiations over the past half century. The reductions in tariff rates have led many of them to resort to discriminatory remedial measures like imposition of antidumping and countervailing duties that are allowed by the GATT Article VI under certain conditions. The U.S. has been the largest user of antidunping and countervailing dutics.

In the U.S., ITC has been in charge of injury determinations regarding administered protection measures such as safeguards, antidumping and countervailing duties. Most papers dealing with the ITC's decisions on administeted protection focused on the economic determinants of antidumping duties (Finger et al. 1982; Moure 1992; Baldwin and Steagall 1994; Hansen and Prusa 1996, 1997; Icidy 1997; Mah 2000; Knetrcr and Prusa 2003; Lec and Mah 2003); most of them with the exception of Baldwin and Steagall (1994) did not compare antidumping duties to councervailing duties. Although Baldwin and Steagall (1994) was unique in comparing these two administered protection measures, the research did not distinguish preliminary from final injury decisions appropriately despite the apparent difference in the share of affirmative injury decisions. Since their work was done before 1995, it could not deal with the experiences under the WTO systcm.

This study reveals the characteristics of U.S. prorectionism by looking at the ITC's decisions on ancidumping and countervailing duties. This includes the significance and macroeconomic determinants of the WTO regulations; differing attitudes of the ITC commissioners depending on their political party affiliation; and the effect of the president's term on the commissioners' antidumping and countervailing decisions. The remainder of this paper is organized as follows: Section 2 explains the institutional characteristics of antidumping and countervailing duties; Section 3 compares the recent tendencies of antidumping and countervailing dutics; Section 4 displays model atsd empirical evidence; and the final section summarizes the overall results.

\section{INSTITUTIONAL BACKGROLND}

\section{Antidumping Duties}

Since dumping is the practice of price discrimination where customers arc charged different prices in international trade to maximize the firms ${ }^{1}$ profits, there is no good economic justification for regarding dumping as particularly harmful (Krugman and Obstfeld 200(b). Dumping, however, has been widely regarded as an unfair practice in international trade. Consequently, GATT Article VI has allowed the contracting 
parties (members of the GATT/WTO) to impose antidumping duties against the exporters' dumped products under certain conditions. For imposition of antidumping duties, there are three basic conditions which need to be satisfied: first, the existence of dumping margin; second, material injury to concerned domestic industries; and third, causal relarionship between dumped imports and material injury to domestic industries. As the average tariff rates have fallen over time with several multilateral trade negotiations, policy makers in many countries have used trade protection measures other than tariff rates, such as antidumping duties, actively.

Although the U.S. actively practiced trade protection measures such as antidumping duties especially since the mid-1970s, the antidumping duties-related regulations date back to the early 1900s when the U.S. enacted two laws directed at low-priced sales by foreign producers, which remain in effect even now. The Trade Act of 1971 marked a watershed in modifications of the trade laws with respect to antidumping.

Currently, antidumping decisions in the U.S. involve several steps. When the Department of Commerce (DOC) receives a complaint of foreign dumping, the International Trade Administration of the DOC evaluates whether dumping has oxcurred. The ITC then determines whether or not the complainant industry is either materially injured or threatened with material injury as a result of the dumped goods. Both agencies make preliminary and final determinations. If the ITC's preliminary determination is negative, the investigation is to be terminated. In case that it is affurmative, the DOC should finish a preliminary and final determination of the dumping margin. In case the DOC makes an affirmative final determination, the ITC is required to make a final determination of injury. If both decisions made by the DOC and the ITC are affirmative, then an antidumping order is issued.

Following ITC ptocedure, material injury is defined vaguely as harm that is not immaterial, insignificant or inconsequential; therefore, the 1TC's decisions on material injury can be made quite subjectively. Aware of the potential for lobbying, the Congress designed the ITC to remain insulated from outside pressure. The six commissioners are appointed by the president, approved by the Senate and all serve a nonrenewable 9 year term. No more than three commissioners may be members of a single political party. A negative ITC decision occurs only when a majority of the ITC commissioners vote that the imports have not caused material injury.

Procedural changes such as filing the antidumping petitions and the 2 per cent de minimis dumping margin criterion were made and the sunset review provision was included in the 1994 Uruguay Round Agreements Act, a result of the settlement of the Uruguay Round. Little changes, however, were introduced with respect to injury and causation. Considering the strengthened Dispute Settlement Mechanism in the WTO, however, beginning from 1995 the ITC commissioners might have become more cautious in injury determinations relating to antidumping cases, which would lower the probability of affirmative injury decisions. Such conjecture would be appealing in the sense that the WTO dispute settlement panels strictly required the authorities to consider all the factors enumerated in Article 3.4 of the Antidumping 
Agreement of the WTO which relates to injury determinations in antidumping cases.

\section{Countervailing Duties}

The traditional argument for countervailing duties is that subsidies distort comparative advantage and lead to resource allocation inefficiency and a reduction in the subsidizing country's economic welfare unless there exists marker failure. In an open economy, government support in the form of export subsidies serves to assist firms in practicing predatory pricing. In this sense, advocates of countervailing duties argue that they are required to level the playing field in international trade. Marvel and Ray (1995) say that antidumping and countervailing duties are almost indistinguishable despite theorctical distinctions. It is noteworthy, however, that one of the important differences between the two is that subsidies are in general the actions of governments themselves. Consequently, the result is that countervailing duties often have a higher level of diplomatic visibility (Jackson 1990 ).

In an institutional aspect, due to the trade impact of subsidies in the sense of injury to the domestic industry of the importing country as well as the inefficient consequences of government intervention (Hufbauer 1983), subsidies are regulated by the current global trading system. The current rules on subsidies and countervailing duties in the mulcilateral trading system are found in the Agrcement on Subsidies and Countervailing Measures of the W'TO as well as Articles VI and XVI of the GATT.

The U.S. has been the world's heaviest user of countervailing dutics, although they have been growing in number and importance outside of the U.S. as well. In the U.S., laws dealing with unfair foreign subsidization date back to the Tariff Act of 1897. However, the use of the U.S. countervailing duties did not become widespread until it was revised in the Trade Act of 1974 . The most important change was to make automatic the private right of action in seeking countervail redress. This, in turn, led to a dramatic increase in the number of countervailing cases in the U.S., and hence escalated international concern (Collins-Williams and Salembicr 1996). The current law regarding courtervailing duties is found in the Trade Agrements Act of 1979, which is an amendment of the Tariff Act of 1930 .

The current U.S. countervailing duty law is subject to the WTO Agreement on Subsidies and Countervailing Measures. Prior to 1995, when the Uruguay Round Agreements Act went into effect, only countries that were signatories of the old lokyo Round Subsidies Code were entitled to an injury test under U.S. law. When non-signatory countries - including tnany less dcveloped countrics - were investigated, it was necessary only for the DOC to find subsidies, and then duties were imposed regardless of their effect on U.S. industries. The absence of an injury test made the countervailing duty law a popular protectionist weapon against the exports of developing countries. Now the injury test has been extenderd to all WTO members (Leibowitz. 2001). 


\section{TENDENCIES OF ANTIDUMPING AND COUNTERVAILING DUTIES}

Table 1 shows that, over the period 1980-1999, the U.S. ITC's annual average prcliminary decisions on antidumping and councervailing duties reached 38 cases and 14 cases respectively. As for the sub-period 1980-1994 before the inauguration of the WTO system, there were 42 cases and 17 cases; however, for the sub-period 1995-1999, they were significantly reduced to 26 cases and 6 cases respectively. Meanwhile, the percentages of the affirmative decisions in the preliminary decision cases on antidumping and countervailing duties were tecorded as 81 percent and 72 percent respectively during 1980-1999. For affirmative decisions regarding antidumping duties, there was an increase from 80 percent in the first sub-period to 87 percent in the second sub-period. For countervailing duties, such percentages increased from 71 percent to 81 percent as well. Taken these two measures together, the percentage of the affirmative decisions increased from 77 percent to 86 percent. The fact that 6 out of 7 decisions in case of the preliminary decisions on antidumping and countervailing duties were made in the affirmative manner under the WTO system sheds light on the future negotiations of such protectionist measures in the global trading system. This demonstrates how stricter conditions for initiating investigations regarding antidumping and countervailing duties need to be developed and stipulated in the WTO regulations to restrain protectionist threats.

Table 1. The ratio of The U.S. I'TC'S Preluminaky Affirma'tive DeCisions/Tu'tal Decisions

\begin{tabular}{cccc}
\hline Period & Antidumping Duties & Councervailing Duties & Total \\
\hline \multirow{2}{*}{$1980-1994$} & $498 / 626$ & $182 / 255$ & $680 / 881$ \\
& $(79.6 \%)$ & $(71.4 \%)$ & $(77.2 \%)$ \\
$1995-1999$ & $115 / 132$ & $26 / 32$ & $141 / 1(4)$ \\
& $(87.1 \%)$ & $(81.3 \%)$ & $(86.0 \%)$ \\
\hline \multirow{2}{*}{$1980-1999$} & $613 / 758$ & $208 / 287$ & $821 / 1045$ \\
& $(80.9 \%)$ & $(72.5 \%)$ & $(78.6 \%)$ \\
\hline
\end{tabular}

Source: U.S. ITC, Annwal Reperts, 1980-1999.

Table 2 shows the U.S. I' 'C's antual average final decisions relating to antidumping duties and countervailing duries reached 25 castes and 11 cases respectively during 1980-1999. As for the sub-period 1980-1994, there were 24 cases and 13 cases; for the sub-period after the inauguration of the WTO system 1995-1999, however, they were recorded as 27 cases and 4 cases respectively. In the case of countervailing duties, the year 1983 can be regarded as an outlier because as many as 51 final decisions were made in that year. Excluding the year 1983 as an outlier, the annual 
average number of final decisions on countervailing duties was some 10 cases in the first sub-period. Taking antidumping and countervailing duties together, the annual average number of these protectionist measures was reduced strictly from 34 cases in the first sub-period to 31 cases in the second sub-period. It means that U.S. protectionism measured by the number of ITC's final decisions relating to ancidumping and countervailing duties did not become weakened significantly with the inauguration of the WTO system. Furthermore, the number of antidumping measures even increased under the WTO system.

\section{Table 2. The Ratio of the US Itc's Final Affirmative Decisions/total DECISIONS}

\begin{tabular}{cccc}
\hline Period & Antidurnping Duties & Countervailing Duties & Total \\
\hline $1980-1994$ & $233 / 357$ & $89 / 193$ & $322 / 550$ \\
& $(65.3 \%)$ & $(46.1 \%)$ & $(58.5 \%)$ \\
$1995-1999$ & $74 / 133$ & $11 / 22$ & $85 / 155$ \\
$-7-6 \%)$ & $(55.6 \%)$ & $(50.0 \%)$ & $(54.8 \%)$ \\
$1980-1999$ & $307 / 490$ & $100 / 215$ & $407 / 705$ \\
& $(62.7 \%)$ & $(46.5 \%)$ & $(57.7 \%)$ \\
\hline
\end{tabular}

Source: U.S. ITC, Annsul Reports, 1980-1999.

During 1980-1999, the percentages of the affirmative injury decisions for final decisions on antidumping and countervailing duties were recorded as 63 percent and 47 percent respectively. Considering that they were substantially lower than those in case of the preliminary decisions, we can say that the Commissioners in the ITC tend to determine the existence of material injury much more cautiously in case of the final decisions as comparcd to the preliminary decisions, or alternatively, we can also say that they tend to show by far a more protectionist position in case of preliminary decisions. In the case of antidumping duties, there was a decrease from 65 percent in the first sub-period to 56 percent in the second sub-period. For countervailing duties, percentages did not change significantly. Taken these two measures together, the percentage for affirmative decisions decreased slightly from 59 percent co 55 percent.

Beginning with the Smoot-Hawley Tariff Act in 1930 until the 1960s, the Democrats in the U.S. backed liberal trade and lower tariffs; meanwhile, the Republicans sought to maintain or increase protection for domestic industry. But, as Destler (1995) argued, such a tendency does nor seem to have been observed in general since the 1970s. Mah (2000) reaffirmed Destler's argument based on the U.S. ITC commissioners' affirmative decisions on antidumping duties during the period 1985-1996.

Since the IJ.S. ITC commissioners' decisions on antidumping and countervailing decisions can differ depending on their political party affiliation, the characteristics 
of the decisions on antidumping and countervajling duties during 1980-1999 are investigated by this affiliation. Table 3 shows the differences between the attitudes of the Democrat Commissioners and those of the Republican Commissioners for antidumping and countervailing duties. Table 3 shows that for preliminary decisions, the percentage of the Republican Commissioners' affirmative votes on antidumping and countervailing duries reached 82 percent, which was about 5 percent higher than that of the Democrat Commissioners. For the final decisions during the period 1980-1999, the percentage of the Democrat Commissioners' affirmative votes on antidumping and countervailing duties was about 4 percent higher than that of the Republican Commissioners. Although the differences between the Commissioners depending on their affiliation were not found in the 1980 s and early 1990s, they became conspicuous in the latter half of the 1990 s for their final decisions on antidumping and countervailing duties.

Table 3. The Ratio of the COMmissioners' AFFikmatrve Votes/Total Votes

\begin{tabular}{ccccc}
\hline \multirow{2}{*}{ Periud } & \multicolumn{2}{c}{ Preliminary } & Democrats & \multicolumn{2}{c}{ Final Democrats } \\
& Democrats & Republicans & Democrats & Republicans \\
\hline \multirow{2}{*}{$1980-1994$} & $1336 / 1753$ & $1812 / 2214$ & $558 / 1043$ & $714 / 1322$ \\
& $(76.2 \%)$ & $(81.8 \%)$ & $(53.5 \%)$ & $(54.0 \%)$ \\
\multirow{2}{*}{$1995-1990$} & $324 / 390$ & $350 / 420$ & $242 / 409$ & $186 / 424$ \\
& $(83.1 \%)$ & $(83.3 \%)$ & $(59.2 \%)$ & $(13.9 \%)$ \\
\hline \multirow{2}{*}{$1980-1999$} & $1660 / 2143$ & $2162 / 2634$ & $800 / 1452$ & $900 / 1746$ \\
& $(77.5 \%)$ & $(82.1 \%)$ & $(55.1 \%)$ & $(51.5 \%)$ \\
\hline
\end{tabular}

Source: U.S. ITC, Amual Reports, 1980-1999.

\section{THE MODEL AND EMPIRICAL EVIDENCES}

Many provisions of the Antidumping and Subsidies Codes in the GATT/WTO have been too vague and the injury determination procedure has been interpreted in different ways. In the U.S., the ITC's injury determination in antidumping and countervailing duties cases can be made by subjective judgment. The commissioners' decisions can be related to the macroeconomic siruation as well, since the commissioners' decisions are likely to affect their job prospects, particularly if one hopes to be appointed to another federal position requiring the nomination of the president. Given the president's views towards the situation of the macroeconomy in tandem with those towards injurious import protection, the commissioners may be tempted to find that deciding in a protectionist direction facing decerioration in the economic situation is helpful in gaining a federal position in the future (Baldwin and Steagall 1994).

Regarding the empirical examination of administered protection measures, authors 
such as Finger, et al. 1982, Herander and Schwartz 1984, Moore 1992, Baldwin and Steagall 1994, Hansen and Prusa 1996, Mah 2000, Knetter and Prusa 2003, and Lee and Mah 2003, among others, examined the effects of domestic as well as international economic variables on the commissioners' antidumping decisions. Leidy (1997) used first-differenced data to avoid problems arising from the use of non-stationary data. Lee and Mah (2003) examined the effect of legislative changes on antidumping decisions in the L.S. None of these works, except for Baldwin and Steagall (1994), distinguished the determinants of countervailing duties from those of antidumping duties, despite the differences. In addition, none of the literature to the author's knowledge deals with the determinants of antidumping and countervailing duties under the WTO system.

Countervailing duties relate to the governmental subsidization in the exporting country; meanwhile, antidumping duties are imposed on dumped imports that result from the exporters' private behavior. In that sense, they are different measures. Subsidization, however, lowers proxfuction cost and may lead to lower export prices; consequently, antidumping and countervailing duties have often becn said to be used interchangeably. There has been little empirical work examining whether the determinants of the two measures are different or not. The comparison of the determinants of antidumping and countervailing duties has policy-wide significance as well. For instance, if decisions on countervailing duties are revealed to be more responsive to changes in macroeconomic variables, it would imply that more lobbying effort is needed to lower the probability of affitmative decisions on countervaling duties-related injury decisions in casc of macroeconomic depression.

The current study reveals the macroeconomic determinants of antidumping and countervailing duties and compares the former with the later. The macroeconomic determinanes of the number of antidumping or countervailing duties include trade balance and import penetration ratios as the international economic factors, with gross domestic product (GDP) growth rates and unemployment rates as the domestic economic factors. One of the aspects which also distinguishes the current study from other previous works is that the current study examines the effect of the president's term on the commissioners' protectionist attitudes, which is captured by a dummy variable. For this case, the following equation is considered:

$$
\begin{aligned}
\text { ADAV(or CVAV) })_{t}= & a+b \mathrm{~TB}_{t}+c \mathrm{IP}_{\mathrm{r}}+\mathrm{d} \mathrm{GY}_{\mathrm{t}}+\mathrm{e} \mathrm{UN}_{\mathrm{r}} \\
& +\mathrm{f} \text { PRESDUM }_{\mathrm{r}}+\mathrm{v}_{\mathrm{t}}
\end{aligned}
$$

ADAV = the number of the commissioners' affirmative votes with respect to the final antidumping decisions; CVAV = the number of the commissioners' affirmative votes with respect to the final decisions on countervailing duties; $\mathrm{TH}=$ trade balances defined by exports subtracted by imports (measured in \$ billions); IP = import pentetation ratio $(\%) ; G Y=$ real $G D P$ growth rate; and $U N=$ unemployment rate 
(\%). PRESDLM $=1$ during President Clinton's first term and $=0$ during his second term. $\mathrm{V}$ is mping decisions; $\mathrm{CVAV}=$ the number of the commissioners' affirmative votes with respect to the final decisions on countervailing duties; $T B=$ trade balances defined by exports subtracted by imports (measured in \$ billions); IP = import penetration ratio (\%); GY = real GDP growth rate; and $\mathrm{UN}=$ unemployment rate (\%). PRESDUM $=1$ during President Clinton's first term and $=0$ during his second term. $\mathrm{V}$ is the conventionally assumed disturbance term.

The quarterly data set covers the period 1995: I 1999: III. Regarding the data appearing in the publications of the U.S. ITC since 1999, IV are not consistent with those until 1999 and III are not included in the current study. Data for TB, IP, GY, and UN are constructed from IMF, International Financial Statistics Yearbook, and data for ADAV and CVAV are observed from the Annual Repons of the U.S. International Trade Commission, 1995-1999. The present paper concentrates on the final injury decisions to focus on actual protection instead of protectionist threats. For the signs of the coefficients in equation (1), as the trade balances improve or the real GDP growth rate increases, the commissioners would not be tempted to vote for in a protectionist manner; therefore, $b<0$ and $d<0$ are expected. As either import penetration ratio or unemploymenc rate increases, they would tend to vote affirmatively with respect to their injury decisions on the administered protection measutes, tesulting in $c>0$ and $\mathrm{e}>0$. The actual determinants of countervailing duty may be revealed to be different from those of antidumping duty in the sense that the commissioners may react more diplomatically with respect to the former, since the government subsidization of exporting countries gives tise to countervaling duty cases.

Although equation ( 1 ) includes trade balances as an explanatory variable, we might think of import volume as an additional international economic variable. Meanwtile, to save the degrees of freedom and to avoid the scrong multi-collinearity between trade balances and import, it is not included in the righe hand side of the equation (1). We can also think of the technological factor. For instance, as the exporting countries' technological level improves, chances are the U.S. market becomes more vulnerable to imports from those countries and, thereby, the U.S. ITC's decision could become more protectionist. Changes in the exporting countries' technological level and the consequent rise of import of the importing country are partly reflected in changes in import penetration ratio in equation (1).

The data period of the current study covers President Clinton's presidency. When his first term ended, he won recelection in 1996. We may hypothesize that in the first term, the president may be interested in protecting certain industrics such as chemical and steel industries; however, in the second term, he would be more interested in overall national welfare, consequently in favor of more liberal trade. If the commissioners consider such attiqudes of the president, their votes would be more in favor of affirmative votes regarding the injury decisions in the president's first term, resulting in $f>0$. 
The ordinary least squares (OLS) estimation results based on data for the ITC's final injury decisions comprising both the Democrat and Republican Commissioners are provided in Table 4. It shows that most signs of the estimated coefficients are consistent with the a priori expectation, except for GY, which is plausible in the sense that the real GDP growth rate data are not available within the concerned quarter. Trade balances and unemployment rate are revealed to be significant in antidumping as well as countervailing duty cases. The commissioners are revealed to consider the macroeconomic situation more seriously for countervailing duties-related decisions than the antidumping duties-related cases. PRESDUM is revealed not to be significant and, furthermore, worsens the overall estimation results, which is robust to various modifications of the explanatory variables. Compared with the results of the previous literature based on the data before the WTO system, Baldwin and Stengall (1994) reported the import penetration ratio to be significant in determining antidumping and countervailing dutics. Hansen and Prusa (1996) also reported that it is significant in determining ancidumping duties. However, it is revealed not to be significant in the current study using the data during 1995-1999.

Tabif: 4. Determinants of the Commissioneks' Votes (1995-1999)

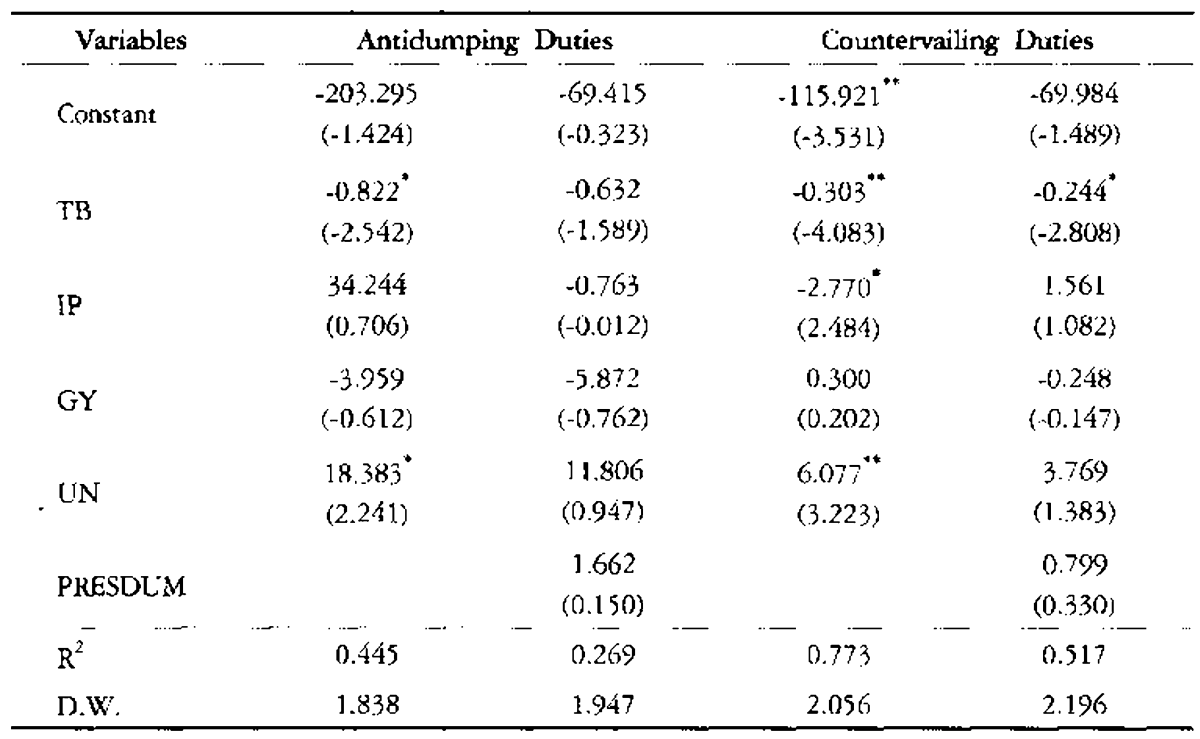

Note: Yalues wiebin the parentheses below the estimated coefficients denote the t-statistics.

.. Statistically significant at 5 per cent level of significance

*- Statistically significant at 1 per cent level of significance

There may be some partisan characteristics in the commissioners' votes with respect to antidumping and countervailing duties. Table 5 reports the estimation results depending on the commissioners' affiliation with the political parties. It shows that 
Democrat and Republican Commissioners are not different with respect to the antidumping duties-related injury decisions. Meanwhile, as for the countervailing duties-related injury decisions, the Democrat Commissioners tend to care somewhat more about the macroeconomic situation than the Republican Commissioners. Since the Democrat Commissioners tended to be more protectionist with respect to their final decisions since the 1980s, unlike the Republican Commissioners they might have been seriously concerned about changes in the macroeconomic situation in case of countervailing duties-related decisions which relate to intergovernmental matters.

Table 5. Determinants of the Commissjoners' Votes by Parties (1995-1999)

\begin{tabular}{lcccc}
\hline \multirow{2}{*}{ Variables } & \multicolumn{2}{c}{ Antidumping Duties } & \multicolumn{2}{c}{ Countervailing Duties } \\
& Democrats & Republicans & Dernocrats & Republicans \\
\hline \multirow{2}{*}{ Constant } & -125.590 & -77.705 & $-68.790^{* *}$ & $-47.132^{\circ}$ \\
& $(-1.476)$ & $(-1.267)$ & $(-3.945)$ & $(-2.899)$ \\
TB & $-0.465^{\circ}$ & $-0.356^{\circ}$ & $-1.187^{\circ *}$ & $-0.116^{* *}$ \\
& $(-2.416)$ & $(-2.567)$ & $(-4.747)$ & $(-3.153)$ \\
IP & 2.169 & 1.255 & $1.563^{\circ}$ & $1.207^{*}$ \\
& $(0.751)$ & $(0.603)$ & $(2.639)$ & $(2.186)$ \\
GY & -2.275 & -1.685 & 0.358 & $-(1.058$ \\
& $(-0.590)$ & $(-0.606)$ & $(0.453)$ & $(-0.079)$ \\
IN & $11.313^{\circ}$ & 7.070 & $3.896^{* *}$ & $2.181^{*}$ \\
& $(2.315)$ & $(2.007)$ & $(3.890)$ & $(2.336)$ \\
\hline R & 0.429 & 0.443 & 0.808 & 0.701 \\
D.W. & 1.766 & 1.965 & 2.018 & 2.133 \\
\hline
\end{tabular}

Note: Values within the parentheses below the estimated coefficients denote the $t$-sratistics.

- Statistically significant at 5 per cent level of significance

** Statistically significant at 1 per cent level of significance

Considering that import penetration ratios and real GDP growth rates are in general not significant in explaining the commissioners' injury decisions, I re-estimated equation (1), temoving IP and GY. Table 6 shows the estimation results do not change qualitatively. In other words, trade balances and unemployment rate are statistically significant in antidumping duties-related decisions. Democrat Commissioners are revealed to be more responsive to macroeconomic variables, such as trade balances and unemployment rate, than the Republican Commissioners in both the absolute values of the coefficients and the t-statistics. Comparing antidumping duties with countervailing duties, the explanatory power of macrocconomic variables is higher in the latter case. It may be because the commissioners consider the specific industry-related factors seriously in case of the private exporters-related antidumping duty cases and also the macroeconomic situation with respect to the countervailing duty injury decisions. 
Table 6. Determinants of the Commissioners' Votes by Parties (1995-1999): TB AND UN AS IHE DETERMINANTS

\begin{tabular}{lcccc}
\hline \multirow{2}{*}{ Variables } & \multicolumn{2}{c}{ Antidumping Duties } & \multicolumn{2}{c}{ Countervailing Duties } \\
& Democrats & Republicans & Democrats & Republicans \\
\hline \multirow{2}{*}{ Constant } & $-71.033^{*}$ & $-46.847^{*}$ & $-25.656^{* *}$ & $-1.1 .160^{*}$ \\
& $(-2.445)$ & $(-2.252)$ & $(-3.645)$ & $(-2.323)$ \\
\multirow{2}{*}{ Tl3 } & $-0.528^{* *}$ & $-0.393^{* *}$ & $-0.235^{* *}$ & $-0.152^{* *}$ \\
& $(-3.178)$ & $(-3.298)$ & $(-5.828)$ & $(-4.277)$ \\
UN & $10.696^{*}$ & $6.794^{*}$ & $3.014^{*}$ & 1.573 \\
& $(2.428)$ & $(2.154)$ & $(2.823)$ & $(1.666)$ \\
\hline R & 0.387 & $0.410^{*}$ & 0.712 & 0.597 \\
D.W. & 1.681 & 1.833 & $1.68]$ & 1.794 \\
\hline
\end{tabular}

Note: Values within the parentheses beiow the cstimared coeificients denote the e-statisrics.

* Statistically signiêcan: at 5 per cent level of significance.

* Statistically significant at l per cent level of significance

\section{CONCLUSION}

Although there have been several works dealing with the macroeconomic determinants of the U.S. ITC's injury decisions with respect to the antidumping cases, most of them did not compare the characteristics of ancidumping duties with those of countervailing duties. Furthermore, despite substantial changes in the trade regulations with the inauguration of the WTO system, the impact of such institutional changes on the determination of antidumping and countervailing duties has not been revealed. Unlike the previous literature, the current study compares the detcrminants of ancidurnping dutics with those of countervailing duties since the inauguration of the WTU system.

The empirical evidence in the current paper shows that the commissioners of the U.S. ITC are responsive to the macroeconomic situacion such as changes in trade balances and unemployment rate. The U.S. president's term is revealed nor to influence the commissioners' decisions. Their decisions in case of antidumping duties are revealed to be less responsive to clanges in such macroeconomic variables than those relating to countervailing duties. By affiliation with political party, the Democtat Commissioners are revealed to be mure responsive to macrocconomic variables than the Republican Commissioners in case of countervailing dutics-related decisions. Although changes in domestic as well as foreign political situations may influcnce the overall results, they are not studied in the present paper and therefore leave much room for future research. 


\section{REFERENCES}

Baldwin, R. E. and J. W. Steagall. 1994. An Analysis of ITC Decisions in Antidumping, Countervailing Duty and Safeguard Cases. Weltwirtschaftliches Arcbiv 130: 290-308. Collins-Williams, Terry and Gerry Salembier. 1996. International Disciplines on Subsidies. Journal of World Trade, 30.

Destler, I. M. 1995. American Trade Politics. 3rded. Washington DC: Institute for International Economics.

Finger, J. M., H. K. Hall, and D. R. Nelson. 1982. The Political Economy of Administered Protection. American Economic Review 72: 452-66.

Hansen, W. L. and T. J. Prusa. 1996. Cumulation and ITC Decision-making: the Sum of the Parts is Greater than the Whole. Economic Inquiry 34: 746-69.

Hansen, W. L. and T. J. Prusa. 1997. The Economics and Politics of Trade Policy: An Empirical Analysis of ITC Decision Making. Review of Intemational Economics S: $230-45$.

Huhbauer, Gary Clyde. 1983. Subsidy Issues After the Tokyo Round. In Trade Policy in the 19805 , ed. William R. Cline. Washington, D.C.: Instirute for International Economics.

Jackson, J. H. 1990. Dumping in International Trade: Its Meaning and Context. In Antidumping Law and Practice: A Comparative Study, eds. John H. Jackson and Edwin A. Vermulst. New York: Harvester Whearsheaf.

Knetter, Michael M. and Thomas J. Prusa. 2003. Macroeconomic Factors and Antidumping Filings: Evidence from Four Countries. Joumal of International Ecmomics 61: 1-17.

Krugman, Paul R and Maurice Obstfeld. 2000. International Economics. 5th ed. Reading, MA: Edison-Wesley Publishing Co.

Lee, Kyung-Ho and Jai S. Mah. 2003. Institutional Changes and Macroeconomic Variables in the United States. Joumal of Policy Modeling 25: 555-65.

Leibowitz, Lewis E. 2001. Safety Valve or Flash Point? The Worsening Conflit between U.S. Trade Laws and WTO Rules. Cato Institure.

Leidy, M. P. 1997. Macroeconomic Conditions and Pressures for Protection under Antidumping and Countervailing Duty Laws: Empirical Evidence from the United States. IMF Staff Papers 44: 132-44.

Mah, J. S. 2000. The United States Antidumping Decisions against the Northeast Asian Dynamic Economies. The World Economy 23: 721-32.

Marvel, H. P. and E. J. Ray. 1995. Countervailing Duties. Economic Joumal 105: 1576-93. MoGrec, Robert W. 1994. A Trade Policy for Free Srieties. Iondon: Quorum Books.

Morore, M. O. 1992. Rules or Politics? An Empirical Analysis of ITC Anti-dumping Decisions. Econonitic Injury 30: 449-66. 